\title{
RevIEW | Living Politics, Making Music: The Writings of Jan Fairley
}

Simon Frith, Stan Rijven and lan Christie Eds.

Farnham: Ashgate, 2014

ISBN 978-1-4724-1266-9

\author{
Katia Chornik \\ University of Manchester \\ katia.chornik@manchester.ac.uk
}

This book compiles a selection of works by the late Jan Fairley (1949-2012), Edinburgh-based writer, broadcaster, ethnomusicologist, and DJ, as well as a central figure to the development of IASPM. Most of her work was on Latin America, with a focus on Chile and Cuba. She was also keenly interested in Andalusian flamenco of post-Franco Spain. Fairley was one of the very few UK scholars working on Latin American music in the seventies and eighties. She followed in the steps of Oxford University's literary scholar Robert Pring-Mill (1924-2005), an expert in Latin American popular poetry and song, best known for his work on Pablo Neruda.

On a recent trip to Chile, I paid a visit to the Archivo de Música Popular Chilena (AMPUC) at the Catholic University of Chile, which holds Fairley's materials on Chilean music. I was struck by the scope and value of her collection, particularly of her audio records. These impressive primary sources were generously donated by Fairley shortly before her death in 2012, and are now available to local scholars as well as members of the public.

Frith, Rijven and Christie's edited collections contains Fairley's articles originally published between 1984 and 2012, including formal academic analyses, historical overviews, conceptual reflections, autobiography, journalism, interviews and even a record review. The material is organized in four sections: "Nueva Canción: Writings on Chile"; "Making Sense of World Music"; "Writings 
on Cuba"; and "Profiles of Music-Makers". Frith and Rijven author two separate introductory chapters, whilst Christie provides the afterword.

The editors' syntheses of Fairley's methodological premises, the ways in which her different professional hats nurtured each other, her plea for popular music studies to embrace phenomena beyond Anglo-American music, her roles in the journal Popular Music and other periodicals and as one of the founding members of the International Association for the Study of Popular Music are all informative. Given the central place of Latin America in her work, it might also perhaps have been helpful to mention her regular contributions to the Latin American branch of the IASPM (IASPM-AL, the main regional forum in popular music studies) and the Latin American Music Seminar (the main forum on Latin American music in the UK).

The editors have done a good job of editing Fairley's works for "repetition, stylistic awkwardness, misprints and redundant references" (Frith: 1), making the bulk of the text very readable. As expected of studies of music phenomena of, or relating to, Spanish-speaking countries, in Fairley's work there is substantial use of the Spanish language. This unfortunately also includes a certain number of linguistic errors in names, terms and quotations from her interviewees, which tend to distract the Spanish-speaking reader and detract from the reading experience. There is some gender confusion in the grammar, as well as typos and missing or misplaced written accents. You might expect these matters to have been raised by peers before these works were first published. The edition would also have benefited from more careful indexing: as well as typos in respect of Spanish names, there are a few page numbering errors.

Linguistic details aside, there is no question that this volume is an important contribution to the growing area of Latin American music studies in the UK, and to popular, world music and journalism studies more generally. Fairley's writings are still inaccessible to the substantial number of Latin Americans with insufficient or non-existent competence in the English language, including local scholars and, following the efforts of the editors in seeking to make Fairley's work more widely available (and in line with the growing concerns about cultural retribution) let us hope that her writings may in due course be translated into Spanish. Her breadth of interest and insights into her research materials would certainly be of wider value than solely to Latin Americanists in English-speaking countries. 